\title{
Determination of heavy metals in drinking water and their adverse effects on human health. A review
}

\author{
Muhammad Tahir Shah ${ }^{1,2,3 *}$, Muhammad Suleman ${ }^{2,3,4}$, Abdul Baqi ${ }^{1,3}$, \\ Samiullah $^{1}$, Abdul Sattar ${ }^{1,2,3}$, Naqeebullah Khan ${ }^{1}$ and Attiq-ur-Rehman ${ }^{1}$ \\ 1. Department of Chemistry, University of Balochistan, Quetta 87300-Pakistan \\ 2. Balochistan Residentail College, Loralai-Pakistan \\ 3. Colleges, Higher and Technical Education Department, Balochistan, Quetta-Pakistan \\ 4. Institute of Biochemistry, University of Balochistan, Quetta 87300-Pakistan \\ *Corresponding author's email: tahirshah1078@gmail.com
}

Citation

Muhammad Tahir Shah, Muhammad Suleman, Abdul Baqi, Samiullah, Abdul Sattar, Naqeebullah Khan and Attiqur-Rehman. Determination of heavy metals in drinking water and their adverse effects on human health. A review. Pure and Applied Biology. Vol. 9, Issue 1, pp96-104. http://dx.doi.org/10.19045/bspab.2020.90012

\begin{tabular}{llll}
\hline \hline Received: 17/06/2019 & Revised: 28/08/2019 & Accepted: 10/09/2019 & Online First: 20/09/2019 \\
\hline \hline
\end{tabular}

\section{Abstract}

The toxicity of heavy metals in drinking water has turned out to be a serious danger for human being and there are numerous problems related to it. Therefore, this study is conducted to explain the heavy metals contamination in drinking water and their related health effects. The dangerous impacts of these metals, without any biological role, exist in minor or another form perilous for man and its body functioning. Either they may work as a pseudo constituent of the body or may interfere with the metabolic activity of human body. Scarcely, any metal like aluminum can be expelled from water through various techniques while few metals get gathered in the body and evolved way of life, displaying a perpetual nature. Different general procedure have been adopted to control as well as to treat metal poisonous quality happening at different dimensions, for example, word related exposure, mishaps and natural factors. Metal lethality relies on the consumed portion, the course of exposure and span of contact, like intense or incessant. This can lead to different disarranges and can likewise result in over the top harm because of oxidative stress initiated by free radical generation. However, this review states the assessment of heavy metals in drinking water and their adverse health effects on human beings. This study will help researchers to acquire knowledge about heavy metals found in drinking water.

Keywords: Drinking water; Exposure; Free radicals; Heavy Metals

\section{Introduction}

The particular substances like metals have high thermal and electrical conductivity, adaptability and sparkle which deliberately lose electrons and produce positives ions. Metals normally exist in the earth's external layer and their pieces differ in different zones, achieving spatial assortments of enveloping obsessions. In air, the dispersal of metal is seen through the characteristics of specific metal along with several natural factors [1]. An understanding regarding the sources of fundamental metals along with their unsafe impacts on nature and living creature are the basic focus of this review. Significant metals are considered as those 
metals which have an undisputable thickness of in overabundance of $5 \mathrm{~g} / \mathrm{cm}^{3}$ and horribly impact the earth and living creatures [2]. These metals are crucial to keep up various biochemical and physiological limits in living creatures exactly when in low centers, at any rate they advance toward getting to be noxious when they outperform certain levels. Regardless of the way, it is observed that heavy metals have various disagreeable prosperity effects and prop up for a huge parcel of time, heavy metals exposure continue and are extending in various regions of world. In addition, heavy metals are basic common toxic substances and their danger is an issue of extending significance for organic, transformative, dietary and specific reasons $[3,4]$. The most normally heavy metals found in waste water are copper, arsenic, lead, chromium, cadmium, nickel and zinc that pose threats for man prosperity and nature [5]. In surroundings, heavy metals enter by normal strategies and via human actions. Diverse origins of heavy metals consolidate soil breaking down, urban flood, common weathering of the world's covering, mining, different modern wastes, sewage discharge, creepy crawlies or ailment control specialists utilized to crops and various others [6]. It likewise demonstrates the whole world generation and use of chosen hazardous metals during 1850-1990. Turn a blind eye to the way that these metals have noteworthy natural limits in plants and animals, at times their substance coordination and oxidation-decline properties assigned them an extra preferred perspective with the objective that they can gain escape power frameworks for instance, homeostasis, compartmentalization, transport and authority to require cell components. Moreover, such metals tie with protein regions that are not formed for them by dislocating one of a kind metals from their typical limiting goals causing separating of cells.

\section{Toxicity of heavy metals}

The toxic metals mostly exist in urban, municipal and industrial runoff that may be harmful to biotic as well as human's lives. The increased industrialization and urbanization are thought to be an increased range of these metals, specifically the heavy metals [7]. More harmful chemical elements if discharge in the environment, absorbed in the soil and become the part of water bodies by the natural process [8]. Generally, there are fifty elements that may be categorized as heavy metals out of which seventeen elements are considered to be harmful and comparatively easily available. Usually, the positive ions have their significant function in drinking water, consequence also demonstrate affecting the humans health [9]. The level of toxicity depends on the kind of metal, its biological function as well as the types of organism which are exposed to it. These heavy metals have great effect on the aquatic fauna and flora which disturb the food chain and usually affect the human beings as well [10]. The heavy metals poisoning to human beings are lead, copper, cadmium, chromium, zinc and iron etc., mostly present in drinking water. These metals are required by the human body in small quantity but, can also be harmful in greater quantity.

\section{Contamination of drinking water}

The drinking water are contaminated by the presence of various toxic chemical compounds, fertilizers and microorganism. Among the inorganic contamination of the drinking water, the heavy metals are getting significance due to their non-degradable nature and high concentration can cause serious biological efforts set up by WHO and EPA (Environmental Protection Agency).

\section{Influence of heavy metals}

There are thirty five metals that are of worry for us because of occupational as well as residential disclosure. Among them, twenty three heavy metals like antimony, bismuth, 
arsenic, cadmium, chromium, cerium, gold, cobalt, copper, gallium, iron, lead, manganese, mercury, nickel, platinum, silver, tellurium, thallium, tin, uranium, vanadium and zinc are hazardous to human. Furthermore, such heavy metals regularly occur in diet and environment. In little quantity, they are needed to keep up great wellbeing however, in greater numbers they can be usually toxic. Heavy metal poisonous quality can make down liveliness stages and damage the function of the brain, blood composition, liver, kidney and other vital organs. In the long run, exposure can develop slowly advancing physical, strong and neurological degenerative procedures that minimize illness for example, Parkinson's sickness, Alzheimer's infection, numerous sclerosis what's more, muscular dystrophy. However, high usage of few metals and their constituents can pose disease especially tumor [11]. The harmfulness range of different heavy metals is high than recommended amounts and found in earth. Henceforth, intensive information of heavy metals is wholly vital by giving legitimate protective measures against their intemperate contact $[12,13]$.

\section{Arsenic}

Arsenic contaminations have happened on account of the two qualities like geologic strategies and the actions of man. Anthropogenic means of arsenic consolidate man doings, for instance, mining and treatment of minerals. Arsenic can be released into the soil and air by refining [14]. The dispatch and overflow of surface water through ground water can be influenced by the above sorts of sources. Other technique of fresh water calumniate is geological sources, for example, arsenic minerals. Many other sources include sedimentary and metasedimentary bed rocks $[15,16]$. Certain number of paints, shades, chemicals, metals, semi-transmitters and drugs have arsenic. Also specific pesticides, fertilizers and animal continuing exercises allow arsenic to the earth in greater amount too. The inorganic kinds of arsenic, for instance, arsenite and arsenate are observed to be continuously hazardous to human prosperity. In addition, they are significantly cancer causing and thus result malignant development of liver, bladder, lungs and skin. Arsenic contaminated water used for drinking is one of the huge explanations behind arsenic harmful quality more than thirty countries on the planet [17]. If the concentration of arsenic focus in underneath water is 10-multiple times than the regard of WHO rule for drinking water $(10 \mu \mathrm{g} / \mathrm{L})$, it might be a danger to people prosperity [18]. Water can be polluted through inappropriately release arsenical engineered substances, arsenical pesticides or by normal mineral stores. Arsenic risk can be either intense or consistent and permanent arsenic poisonous quality is named as arsenicosis. Several works about arsenic poisonousness in man focuses on skin signs in light of its distinction in analysis. Pigmentation just as keratosis are the undisputable skin wounds that exhibit steady arsenic destructiveness [19]. Lower measurements of arsenic indication can cause vomiting, decline age of erythrocytes as well as leukocytes, abnormal heartbeat, pricking sensation in hands as well as in legs and damage to veins. Over the long haul, exposure can provoke the development of skin wounds, inward malignant growths, neurological issues, aspiratory disease, periphery vascular sustenance, hypertension, cardiovascular contamination and diabetes mellitus [20]. Permanent arsenicosis results in various unalterable changes in the fundamental organs and the passing rate is higher. In continuing of the degree of this possibly severe threat, no proper cure for this ailment is seen.

\section{Lead}

Human exercises, for example, mining, producing and petroleum product consuming 
have brought about the collection of lead and its constituents in earth, comprising air, water and soil. Lead is utilized for the generation of batteries, makeup, metal items like ammo, weld, pipes and so on. Lead is exceedingly dangerous and thus its utilization in different items such as paints, petroleum and so forth has been extensively decreased recently. The primary resources of lead introduction are toxic paints, gasoline, makeup, toys, family unit dust, polluted soil, mechanical discharges, etc. [21]. Lead toxicity was viewed as a great illness and the symbols that were found in youngsters and grown-ups were chiefly relating to the focal sensory system and the gastrointestinal tract [22]. Lead harming can additionally happen from drinking water. Channels which are made of lead and its compounds for conveying water can pollute it [23]. As indicated by the EPA; Environmental Protection Agency, the $\mathrm{Pb}$ is viewed as a cancer-causing agent. Lead effectively affects extraordinary portions of whole body. Lead appropriation in body at first relies upon the blood stream into different tissues and round about ninety five percent of lead is stored as unsolvable phosphate in very thin bones [24]. Poisonous quality of lead, likewise named lead harming, moreover intense or endless. Intense introduction may cause loss of hunger, migraine, stomach disorder, kidney dysfunction, exhaustion, restlessness, joint inflammation, mental trips, hypertension and vertigo. Intense presentation chiefly happens in the work environment and in some assembling industries that form utilization of lead. Constant introduction of lead can cause in mental hindrance, birth abnormality, psychosis, chemical imbalance, sensitivities, dyslexia, weight reduction, hyperactivity, loss of motion, muscular shortcoming, cerebrum harm, kidney harm and may even cause passing. It is also confirmed through various studies that greater amount of lead in the bloods may influence an individual's IQ
[25]. Despite the fact that lead harming is curable, it still behaves an unsafe element which can influence majority of the organs. The plasma membrane can move into the small portions of mind when blood cerebrum hindrance is presented to hoisted dimensions of lead focus, coming about called edema. It disturbs the intracellular second errand person frameworks and changes the working of the focal sensory system; whose assurance is very essential. Ecological and residential bases of lead particles are the fundamental driver of the ailment. But with legitimate prudent steps, it is conceivable to decrease the hazard related by lead harmfulness.

\section{Mercury}

Mercury $(\mathrm{Hg})$ is viewed as the highly harmful heavy metal in nature. Its harming is reported to as acrodynia or pink ailment. It is discharged into the surrounding through different enterprises like pharmaceuticals, mash additives and paper, horticulture industry, and chlorine and acidic soft drink production industry [26]. Mercury has the capacity to join with different components and produced natural as well as inorganic $\mathrm{Hg}$. Contact to hoisted dimensions of metallic, natural and inorganic mercury that can harm the mind, kidneys and evolving embryo [27]. Mercury is available in many food items and drinks in the run $<1$ to $50 \mu \mathrm{g} / \mathrm{kg}$. In marine nourishments, it is frequently observed at more elevated amounts. Natural mercury can definitely diffuse over the bio-membranes and meanwhile they are lipophilic naturally, mercury is available in large quantities in many types of slippery as well as in the liver of slim fish. In smaller scale, living beings change the mercury existing in earth and water into $\mathrm{MeHg}$, a poison which can gather is normal. Likewise, in different conditions, it might be troublesome to analyze such cases. Due to the overabundance wellbeing impacts related with introduction to $\mathrm{Hg}$, the current parameter for drinking water was 
arranged in lesser dimensions of $0.002 \mathrm{mg} / \mathrm{L}$ and $0.001 \mathrm{mg} / \mathrm{L}$ by the EPA and WHO [28].

\section{Cadmium}

Cadmium (Cd), a metal of the twentieth century, is the side-effect of zinc creation. Rock and soils including mineral and coal components comprise certain quantity of cadmium. It has various advantages, for instance in metal coatings, batteries, plastics, shades and is comprehensively used in electroplating [29]. Cd and its components are named as Group 1, cancer causing agents for people, by the IAR "International Agency for Research" on malignant development [30]. It is eliminated into the earth through trademark doings, for example, volcanic discharges, chemical weathering, stream transport and a couple of human activities like mining, refining, tobacco smoking, burning of city waste and making of different fertilizer. In spite of the way that cadmium release was obviously diminished in many developed countries, it is residual source of genuine worries for authorities and public residing in contaminated regions. It can result both permanent and strengthened, interminable [31]. Cadmium is significantly deadly to kidney and it gathers in the proximal tube shaped cells in larger amounts. It may reason bone diseases and damage. Osteoporosis (skeletal damage), a fundamental effect of cadmium, focuses on individuals and different animals have unearthed along with agitating impacts in $\mathrm{Ca}$ absorption (hypercalciuria). Taking in increasingly elevated measures of cadmium can make extraordinary harm to the lungs. If cadmium is consumed in higher amount too, it can provoke stomach exacerbation and achieve hurling and detachment of the intestines. On very long presentation period at lower amount, it can advance toward getting to be kept in kidney that cause renal ailment [32]. Cd as well as its various compounds are exceedingly water soluble taken a gander on to various metals. The bioaccumulation of $\mathrm{Cd}$ is very high owing to its bioavailability. High amount of $\mathrm{Cd}$ can pose in morph pathological variations in kidneys. Tobacco, a key source of $\mathrm{Cd}$, inhale by smokers as various plants obtain total $\mathrm{Cd}$ from the soil. However, non-smokers are exhibited to cadmium by methods for sustenance and a couple of various pathways. Be that as it may, cadmium take-up through various pathways is much lower [33]. Cadmium teams up with basic enhancements through which it results its toxic quality effects. Test examination in animals has seemed half of $\mathrm{Cd}$ are engrossed in lungs moreover, less in the gastrointestinal tract. Unfavorable birth and decreased birth loads are the problems that rise if cadmium overview is high especially in human pregnancy [34].

\section{Chromium}

It is generally available in rocks, plants, soil and animals. It tends to be present in the state of solid, fluid and as gas. Chromium components are especially relentless in water dregs. They can happen in various states, for example, divalent, tetra-valent and pentavalent as well as hexavalent states. Chromium (VI) and Chromium (III) are generally most stable states and just their connection to human body contact is of great matter of curiosity [35]. Cr (VI) compounds like strontium, lead, zinc and calcium chromates are exceedingly toxic and cancer causing-agents in natural surroundings. Chromium (III), then again, is a basic wholesome enhancement for creatures and people and has a critical job in glucose digestion. The take-up of $\mathrm{Cr}^{+6}$ (hexavalent chromium) constituents through the air routes and stomach related channel is quicker as compared to $\mathrm{Cr}^{+3}$ (trivalent Cr-compounds). Word related sources of $\mathrm{Cr}$ incorporate defensive metal coverings, metal amalgams, dye colors, elastic, concrete, paper, wood additives, calfskin tanning and metal plating. It is also demonstrated that cigarettes 
contained three hundred and nighty gram per kilogram of $\mathrm{Cr}$, yet no proper document is reported on such a huge quantity of chromium breathed in through smoking. At the point when broken skin interacts with any sort of chromium intensifies, a profoundly infiltrating opening will be framed. The development of ulcers is the result of contact to chromium compounds which will persevere for months and wound gradually [36]. Ulcers present in nasal septum are exceptionally regular in the event of chromate specialists. Contact to greater concentration of $\mathrm{Cr}$-compounds in people can promote the restraint of erythrocyte glutathione reductase, which thus brings down the ability to diminish methemoglobin to hemoglobin [37]. The results got from various explores appeared that chromate can prompt DNA harm in diverse means and can prompt the arrangement of DNA adducts, chromosomal variations, modifications in replication and interpretation of DNA [38].

\section{Iron}

It is the most abundant metal on the planet. Normally, it is the furthermost basic enrichment for many active individuals being the cofactor for some essential proteins as well as enzymes. Iron facilitated responses back up a large protein consuming living creatures in their breath methodology. However, the unmanageable Fe can initiate responses including the creation of radicals which can hurt biomolecules, tissues, cell and the whole living being. Ferrum harming has constantly been a point of enthusiasm for the most pediatricians. Youths are extraordinarily helpless to iron danger as they are on contact to a furthest ranges of $\mathrm{Fe}$ consisting things [39]. Iron toxicities arises in 4 stages. The vital instigator which happens following six hours of iron overdose is separated by gastrointestinal effects for instance, gastro intestinal draining and detachment of the guts. The second stage propels inside six to twenty-four hours of overdose and considered as the dormant period, a time of clear curative treatment. The $3^{\text {rd }}$ phase begins between twelfth to ninety six hours after the start of important clinical symptoms. Such phase is showed by shocks, tiredness, hypotension, hepatic issue, metabolic acidosis and on occasion passing. The fourth stage occurs inside one and half months periods of iron overdose. This stage thought the improvement of intestinal ulcerations and growth of strictures. Plenty iron take-up is a troublesome issue in meateating countries and it extends the threat of malignant development. Authorities who are very exhibited to asbestos that holds for all intents and purposes thirty percent of $\mathrm{Fe}$ are of high threat of asbestosis being the $2^{\text {nd }}$ most fundamental reason for lung malignant development. It is accounted for that asbestos related malignancy is concerned with free radicals. Free intracellular $\mathrm{Fe}$ can moreover force DNA hurt. Fundamentally, iron can begin threatening development by the method of oxidation of DNA particles [40, 41]. Salts of $\mathrm{Fe}$, for instance, $\mathrm{FeSO}_{4}$, $\mathrm{FeSO}_{4} \cdot \mathrm{H}_{2} \mathrm{O}$ and $\mathrm{FeSO}_{4} .7 \mathrm{H}_{2} \mathrm{O}$ are of low serious harmfulness when introduction is through oral, dermal and internal breath courses what's more, in this way they have been set in harmful quality arrangement three. In addition, iron salts are seen as protected by Nourishment and Drug Administration and their risky impacts are particularly unimportant [42-44]. Delivering of free radicals is the after effect of $\mathrm{Fe}$ harmful quality. Amid the regular and over the top cell getting ready, symptoms like superoxide and $\mathrm{H}_{2} \mathrm{O}_{2}$ are confined and considered as free radicals. Consequently, such species are truly executed by synthetics peroxidase and so on. Yet the superoxide species can release Fe from ferritin and that free $\mathrm{Fe}$ combine with surrounding uncommonly perilous free radicals i.e., hydroxyl radical can deactivate certain synthetic substances, begin fat peroxidation 
and depolymerize the polysaccharides. This can a portion of the time bring about breaking the DNA strand.

\section{Conclusion}

In this study, the impacts of certain heavy metals like, chromium, arsenic, cadmium, mercury, lead and iron on the ecosystem and living organisms specifically individuals are studied. Productive legislation, framing of rules and identification of the regions where these heavy metals are present in excessive amount, would be made on emergency basis. Inability to control the exposure will result in extreme difficulties later on in view of the unfavorable impacts produced by heavy metals. Observing the contact and probably interference for decreasing extra contact to heavy metals in nature what's more, in people can turn into a pivotal advance towards counter active action. National just as worldwide co-activity is important for framing immediate tactics to inhibit toxicity of heavy metals.

\section{Authors' contributions}

Conceived and designed the Idea: A Rehman, Samiullah \& MT Shah, Wrote the paper: MT Shah, A Baqi \& M Suleman

\section{References}

1. Khlifi R \& Hamza-Chaff A (2010). Head and neck cancer due to heavy metal exposure via tobacco smoking and professional exposure: A review. Toxicol Appl Pharmacol 248: 71-88.

2. Jarup L (2003). Hazards of Heavy Metal Contamination. Br Med Bul 168 (1): 110.

3. Jaishankar M, Mathew BB, Shah MS \& Gowda KRS (2014). Biosorption of Few Heavy Metal Ions Using Agricultural Wastes. J Enviro Pol \& Hum Heal 2(1): $1-6$.

4. Shruthi KM \& Jeevitha P (2018). Removal of Heavy Metals in Wastewater using Walnut Shells as Adsorbent. Intl J Appl Eng Res 13(7): 241-244.
5. Lambert M, Leven BA \& Green RM (2000). New methods of cleaning up heavy science and Technology briefs for citizens. Kansas State University, Manhattan, KS.

6. Morais S, Costa FG \& Pereira ML (2012). Heavy metals and human health, in Environmental Health emerging issues and practice. Oosthuizen $J$ ed 227-246.

7. Satarug S, Garrett SH, Sens MA \& Sens DA (2011). Cadmium, Environmental exposure and health outcomes. Ciencia \& Saude Coletiva 16(5): 2587-2602.

8. Alina M, Azrina A, Yunus M, Zakiuddin M, Izuan M ,\& Rizal M (2012). Heavy metals (mercury, arsenic, cadmium,plumbum) in Selected Marine fish and shellfish along the Straits of Malacca. Intl Food Res J 19(1): 135-140.

9. Abida $\mathrm{B}$, Harikrishna $\mathrm{S} \&$ Irfanullah $\mathrm{K}$ (2009). Intl J of Chem Tech Res CODEN (USA). IJCRGG 1(2): 245-249.

10. Sardar K, Maria SN, Jahana SR \& Islamud D (2012). J of Cleaner Production xxx 1-9.

11. Ram S, Lokhande PUS, Deepali S \& Pimple (2011). Resou and Environ 1(1): 13-19.

12. Jarup L. (2003). Hazards of heavy metal contamination. Br Med Bull 68(1): 167182.

13. Ahmad MS, Khan ZI, Ahmad K, Batool AI, Hamid S, Sher M \& Ejaz A (2017). Accretion and dispersion of heavy metals in a vegetable grown in contaminated soil with sewage water: a matter of great concern and community health consequences. Feb-Fresenius Envir Bull, 4345.

14. Ferner DJ (2001). Toxicity heavy metals. E Med J 2(5): 1.

15. Sadhu SD, Garg M \& Kumar A (2018). Bhaskaracharya College of Applied Sciences, University of Delhi, New 
Delhi, Delhi, India. New Polym Nanocomp Enviro Remed, 77.

16. Matschullat J, (2000). Arsenic in the Geosphere a review. Sci Total Environ 249(1-3): 297-312.

17. Smedley PL \& Kinniburgh DG (2002). A review of the source, behavior and distribution of arsenic in natural waters. Appl Geochem 17: 517-568.

18. Chowdhury UK, Biswas BK, Chowdhury TR, Samanta G, Mandal BK, Basu GC \& Chakraborti D (2000). Ground water Arsenic Contamination in Bangladesh and West Bengal, India. Environ Health Perspect 108(5): 393397.

19. Radfard M, Yunesian M, Nabizadeh R, Biglari H, Nazmara S, Hadi M \& Mahvi AH (2019). Drinking water quality and arsenic health risk assessment in Sistan and Baluchestan, Southeastern Province, Iran. Hum \& Ecolo Risk Asses: An Inter J, 25(4): 949-965.

20. Hoque MA, Burgess WG, Shamsudduha M \& Ahmed KM (2011). Delineating low-arsenic groundwater environments in the Bengal Aquifer System, Bangladesh. Appl Geochem 26(4): 614623.

21. Martin S \& Griswold W (2009). Human health effects of heavy metals. Environmental Science and Technology Briefs for Citizens (15): 1-6.

22. Smith AH, Lingas EO \& Rahman M (2000). Contamination of drinking-water by arsenic in Bangladesh a public health emergency. Bull World Health Organ 78(9): 1093-1103.

23. Gerhardsson L, Dahlin L, Knebel R \& Schutz A (2002). Blood lead concentration after shotgun accident. Environ Health Perspect 110(1): 115117.

24. Markowitz, M. (2000). Lead Poisoning. Pediatr Rev 21(10): 327-335.
25. Brochin R, Leone S, Phillips D, Shepard N, Zisa D \& Angerio A (2008). The cellular effect of lead poisoning and its clinical picture. GUJHS. 5(2): 1-8.

26. Papanikolaou NC, Hatzidaki EG, Belivanis S, Tzanakakis GN \& Tsatsakis AM (2005). Lead toxicity update. A brief review. Med Sci Monitor 11(10): RA 329.

27. Taylor MP, Winder C \& Lanphear BP (2012). Eliminating childhood lead toxicity in Australia: a call to lower the intervention level. MJA 197(9): 493.

28. WHO (2004). Guidelines for drinkingwater quality. Sixty-first meeting, Joint FAO/WHO Expert Committee on Food Additives, Available from http://ftp.fao.org/es/esn/jecfa/jecfa61sc. pdf).

29. Regoli L (2005). The Relative Contributions of Different Environmental Sources to Human Exposure and the EU Cadmium Risk Assessment Meeting of UNECE Task Force on Heavy Metals. Presentation for the UNECE Long-Range-Transboundary Air Pollutants - Task Force on Heavy Metals 16-18 March, in Berlin.

30. Henson MC \& Chedrese PJ (2004). Endocrine disruption by cadmium, a common Environmental toxicant with par-adoxical effects on reproduction. Exp Biol Med (Maywood) 229(5): 383392.

31. Chakraborty S, Dutta AR, Sural S, Gupta D \& Sen S (2013). Ailing bones and failing kidneys: a case of chronic cadmium toxicity. Ann Clin Biochem 50(5): 492-495.

32. Bernard A (2008). Cadmium \& its adverse effects on human health. Indian J Med Res 128(4): 557-64.

33. Mudgal V, Madaan N, Mudgal A, Singh RB \& Mishra S (2010). Effect of toxic Metals on human health. Open Nutraceuticals J 3: 94-99. 
34. Flora SJS, Mittal M \& Mehta A (2008). Heavy metal induced oxidative stress \& its possible reversal by chelation therapy. Indian J Med Res 128: 501-523.

35. Zhitkovich A (2005). Importance of chromium-DNA adducts in mutagenicity and toxicity of chromium (VI). Chem Res Toxicol 18(1): 3-11.

36. Schroeder HA, Nason AP \& Tipton IH (2009). Chromium deficiency as a factor in atherosclerosis. J Chron Dis 23(2); 123-142.

37. Koutras GA, Schneider AS, Hattori M \& Valentine WN (2008). Studies on chromatid erythrocytes. Mechanisms of chromate inhibition of glutathione reductase. Br J Haematol 11(3): 360369.

38. O'Brien T, Xu J \& Patierno SR (2001). Effects of glutathione on chromiuminduced DNA crosslinking and DNA polymerase arrest. In Molecular Mechanisms of Metal Toxicity and Carcinogenesis 173-182. Springer US.

39. Matsumoto ST, Mantovani MS, Malaguttii MIA, Dias AL, Fonseca IC \& Marin-Morales MA (2006). Genotoxicity and mutagenicity of water contaminated with tannery effluents, as evaluated by the micronucleus test and comet assay using the fish Oreochromis niloticus and chromosome aberrations in onion root-tips. Gene \& Mol Biol, 29(1): 148-158.

40. Morales MA (2006). Genotoxicity and mutagenicity of water contaminated with tannery effluents, as evaluated by the micronucleus test and comet assay using the fish Oreochromis niloticus and chromosome aberrations in onion roottips. Genet Mol Biol 29(1): 148-158.

41. Albretsen J (2006). The toxicity of iron, an essential element. Veterinary Medicine 82-90.

42. Bhasin G, Kauser H \& Athar M (2002). Iron augments stage-I and stage-II tumor promotion in murine skin. Cancer Lett 183(2): 113-122.

43. Fine JS (2000). Iron poisoning. Curr Probl Pediatr 30(3): 71-90.

44. Bosch AC, O'Neill B, Sigge GO, Kerwath SE, \& Hoffman LC (2016). Heavy metals in marine fish meat and consumer health: a review. J Sci of Food \& Agri 96(1): 32-48. 